\title{
KEBIJAKAN PEMERINTAH INDONESIA DALAM MENANGGULANGI COVID-19 BERDASARKAN INSTRUMEN HUKUM INTERNASIONAL
}

\author{
I Ketut Sukawati Lanang Putra Perbawa ${ }^{1^{*}}$ \\ ${ }^{1}$ Universitas Mahasaraswati, Indonesia \\ *e-mail: sukawatilanang@gmail.com
}

\begin{abstract}
Abstrak
Pandemi Covid-19 merupakan wabah penyakit yang mematikan, penyebaran covid-19 di Indonesia sangat mempengaruhi kesehatan masyarakat Indonesia. Tujuan penelitian ini adalah menganalisis kebijakan pemerintah indonesia dalam menanggulangi covid-19 berdasarkan instrumen hukum internasional. Penelitian ini merupakan penelitian studi kasus. Subjek dan objek pembahasan didalam penelitian ini adalah kebijakan pemerintah indonesia dalam menanggulangi covid-19. Metode pengumpulan dalam penelitian ini adalah dengan menganalisis kebijakan-kebijakan yang telah dibuat oleh pemerintah Indonesia. Teknik analisis data yang digunakan pada penelitian ini adalah teknik analisis data statistik kualitatif. Hasil penelitian ini yaitu Indonesia membentuk kebijakan yang dapat menghambat penyebaran covid-19, adapun kebijakankebijakan yang dibentuk oleh pemerintah Indonesia dibagi menjadi dua aspek, pertama dalam hal kesehatan dan kedua dalam aspek hak asasi manusia. Simpulan penelitian ini adalah kebijakan yang dibentuk oleh pemerintah Indonesia dibagi menjadi dua aspek, pertama dalam hal kesehatan dan kedua dalam aspek hak asasi manusia sudah dilaksankan dan diharapkan dapat menanggulangi penyebaran covid-19 berdasarkan instrumen hukum internasional.
\end{abstract}

Kata kunci: Covid-19; Kebijakan; Konvensi Internasional

\begin{abstract}
The Covid-19 pandemic is a deadly disease outbreak, the spread of covid-19 in Indonesia has greatly affected the health of the Indonesian people. The purpose of this study is to analyze the Indonesian government's policies in tackling Covid-19 based on international legal instruments. This research is a case study research. The subject and object of discussion in this study are Indonesian government policies in tackling Covid-19. The collection method in this research is to analyze the policies that have been made by the Indonesian government. The data analysis technique used in this research is qualitative statistical data analysis techniques. The results of this study are that Indonesia forms policies that can inhibit the spread of Covid-19, while the policies established by the Indonesian government are divided into two aspects, first in terms of health and second in aspects of human rights. The conclusion of this research is that the policies formed by the Indonesian government are divided into two aspects, first in terms of health and second in the aspect of human rights that have been implemented and are expected to be able to tackle the spread of covid-19 based on international legal instruments.
\end{abstract}

Keywords: Covid-19; Policy; International Covenant

This is an open access article under the CC BY-SA license.

Copyright @ 2021 by Author. Published by Universitas Pendidikan Ganesha.

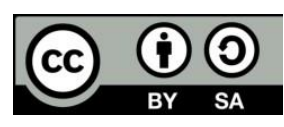




\section{PENDAHULUAN}

Corona Virus Disease 2019 (Covid19) merupakan penyakit yang pertama kali ditemukan di Kota Wuhan, China (Fitriyani et al., 2020; Herliandry et al., 2020; Pratama et al., 2020). Penularan Covid-19 di Republik Rakyat China (RRC) terjadi pada tahun 2019 dan menyebabkan kematian terhadap warga negara RRC. Pada Awal 2020 penyebaran telah meluas hingga ke setiap negara termasuk di wilayah Asia Tenggara yang diawali oleh Negara Singapura dan Malaysia. Kedua negara tersebut menyatakan terpapar virus covid-19 pada bulan February, sehingga baik Singapura dan Malaysia menerapkan kebijakan untuk mengisolasi setiap warganya yang terindikasi positif (Andiarna \& Kusumawati, 2020; Dewi, 2020; Goldschmidt, 2020).

Namun kenyataannya, saat ini penularan Covid-19 terjadi di Indonesia dibandingkan dengan Singapura dan Malaysia, Indonesia baru mengumumkan Kasus Covid-19 pertama kali pada tanggal 2 Maret 2020 yang diumumkan oleh Presiden Jokowi. Kasus masuknya Virus Covid-19 pertama kali ke Indonesia disebabkan 2 Warga Negara Indonesia melakukan kontak fisik dengan warga negara Jepang saat berkunjung ke Indonesia yang diduga positif virus Covid-19. Seminggu setelah kejadian masuknya virus Covid-19 pertama kali di Indonesia tepatnya pada 11 Maret 2020 pemerintah secara resmi mengumumkan bahwa terdapat warga negara Indonesia yang meninggal akibat Virus tersebut.

Penyebaran covid-19 di Indonesia
sangat mempengaruhi kesehatan,
kesehatan yang dimaksud tidak hanya
berupa fisik, namun berpengaruh terhadap
mental health. Karena dibandingkan dengan
aspek yang lain, kesehatan merupakan
salah satu kebutuhan pokok manusia dan
tanpa hidup sehat hidup manusia menjadi
tanpa arti (Anugrahana, 2020; Kurniati et al.,
$2020 ;$ Yunitasari \& Hanifah, 2020).
Meskipun telah terdapat aturan yang

mengatur tentang kesehatan dibawah Undang-Undang Nomor 36 Tahun 2009 tentang Kesehatan, akan tetapi pengaturan untuk menanggulangi penyebaran covid-19 di Indonesia tidak hanya cukup berdasarkan UU Kesehatan saja, dibutuhkan kebijakankebijakan dari pemerintah untuk menanggulangi Covid-19 dengan berdasar kepada ideologi negara dan juga Konvensi Internasional.

Konvensi Internasional dibentuk dibawah naungan organisasi Internasional, sehingga negara-negara yang meratifikasi konvensi tersebut terikat dan tunduk terhadap Konvensi Internasional tersebut sesuai dengan asas Pacta Sunt Servanda (Rahayu \& Febriaty, 2017; Sabet et al., 2018; Suryaman, 2015). Termasuk Indonesia yang telah meratifikasi beberapa Konvensi Internasional kedalam Hukum Nasional beberapa contohnya: UndangUndang No. 11 Tahun 2005 tentang Pengesahan International Covenant on Economic, Social and Cultural Rights, Undang-Undang No. 12 Tahun 2005 tentang Pengesahan International Covenant on Civil and Political Rights (ICCPR), dll. Sehingga, kebijakan yang diterapkan oleh pemerintah didalam penanggulangan Covid-19 berdasar kepada Konvensi Internasional (Galih, 2017; Olivia et al., 2020; Yunus et al., 2020).

Penelitian ini didukung oleh beberapa penelitian sebelumnya yang relevan dengan penelitian ini yaitu: (1) penelitian yang dilakukan oleh (Kurniati et al., 2020), yang mendapatkan hasil penelitian bahwa peran orang tua sangat penting dalam mendampingi anak di masa pandemic covid-19; (2) penelitian yang dilakukan oleh (Fitriyani et al., 2020), yang mendapatkan hasil penelitian bahwa pelaksanaan kegiatan pendidikan dilaksanakan secara daring selama pandemic covid-19; (3) penelitian yang dilakukan oleh (Pratama et al., 2020), yang mendapatkan hasil penelitian bahwa 
penggunaan media pendidikan efektif digunakan dimasa pandemic covid-19. Penelitian lain juga dilakukan oleh (Chen et al., 2021) menyatakan bahwa orang cenderung lebih memperhatikan hasil pertempuran pemerintah mereka melawan COVID-19 (jumlah kasus yang dikonfirmasi dan kematian per juta populasi) daripada kebijakan apa yang dimulai oleh pemerintah mereka. Tujuan penelitian ini adalah menganalisis kebijakan pemerintah indonesia dalam menanggulangi covid-19 berdasarkan instrumen hukum internasional.

\section{METODE}

Penelitian ini merupakan penelitian studi kasus yang dilakukan dengan metode deskriptif dengan pendekatan kualitatif dan studi pustaka. Penelitian ini dilaksanakan untuk menganalisis kebijakan pemerintah indonesia dalam menanggulangi covid-19.

Subjek dan objek pembahasan didalam penelitian ini adalah kebijakan pemerintah indonesia dalam menanggulangi covid-19 berdasarkan instrumen hukum internasional. Metode pengumpulan dalam penelitian ini adalah dengan menganalisis kebijakan-kebijakan yang telah dibuat oleh pemerintah Indonesia untuk mengatasi penyebaran covid-19.

Teknik analisis data yang digunakan pada penelitian ini adalah teknik analisis data statistik kualitatif yang dipandang relevan menggambarkan kondisi yang terjadi pada saat ini dan menjadi latar belakang penelitian yaitu menanggulangi covid-19 berdasarkan instrumen hukum internasional.

\section{HASIL DAN PEMBAHASAN}

Pada masa Pandemi Covid-19, sektor Kesehatan merupakan sektor yang paling krusial. Hal ini disebabkan Covid-19 merupakan salah satu bagian didalam kesehatan yang dapat menyebabkan kematian terhadap seseorang. Maka dari itu, penanggulangan terhadap Covid-19 perlu dilakukan dengan pembentukan kebijakan dari pemerintah.

Kebijakan pemerintah dalam hal ini hanya berfungsi sebagai bagian dari operasional penyelenggaraan tugas-tugas pemerintahan, karenanya tidak dapat mengubah ataupun menyimpangi peraturan perundang-undangan. Kebijakan pemerintah ini sebetulnya menutupi kelemahan dari asas legalitas karena tidak setiap hal terutama dalam masa Pandemi Covid-19 terdapat Undang-undang yang mengaturnya termasuk di bidang kesehatan. Dalam bidang kesehatan terdapat hukum tersendiri yang disebut dengan Hukum Kesehatan. Hukum kesehatan merupakan aturan yang melindungi secara khusus tugas dari profesi atau tenaga kesehatan dalam program pelayanan kesehatan manusia dan perlindungan khusus pula terhadap pasien untuk mendapatkan pelayanan kesehatan (Galih, 2017; Olivia et al., 2020; Yunus et al., 2020). Kebijakan pemerintah didalam menanggulangi Covid19 berbagai macam diantaranya kebijakan untuk memberikan vaksin kepada seluruh Warga Negara Indonesia, Kebijakan Lockdown, Kebijakan pembentukan Protokol Kesehatan, dan masih banyak kebijakan kesehatan lainnya.

Orang-orang bangsa Indonesia asli yang berada diluar negeri maka orang-orang tersebut termasuk kedalam Warga Negara Indonesia. Sehingga Negara memiliki tanggung jawab untuk melindungi mereka termasuk dalam hal kesehatan. Salah satu contoh, Indonesia melakukan evakuasi dan pemulangan terhadap Warga Negara Indonesia yang terdapat di Republik Rakyat China dikarenakan Negara tersebut mengalami krisis akibat virus Covid- 19 .

Dalam hal mencegah penyebaran virus Covid-19 alat yang paling ampuh untuk melakukan hal tersebut ialah Vaksin. Tujuan dari Vaksin ialah untuk memberikan kekebalan terhadap penyakit, sehingga apabila tidak terdapat manfaat dari vaksin tersebut maka tidak akan ada kekebalan 
terhadap tubuh pengguna vaksin dan lebih mudah terserang penyakit (Olivia et al., 2020; Pratama et al., 2020; Yunus et al., 2020). Pengaturan terhadap Vaksin Covid19 terdapat dalam Peraturan Presiden No.99 Tahun 2020 tentang Pengadaan Vaksin dan Pelaksanaan Vaksinasi Dalam Rangka Penanggulangan Pandemi Corona Virus Disease 2019 (Covid-19) (Perpres Vaksin) dan Peraturan Menteri Kesehatan (PMK) Nomor 84 Tahun 2020 tentang Pelaksanaan Vaksinasi dalam Rangka Penanggulangan Pandemi Covid-19 (PMK Vaksin). Perpres Vaksin sebagian besar mengatur mengenai kerjasama terhadap pendistribusian vaksin dan juga beberapa peran didalam melaksanakan pendistribusian vaksin di Indonesia. Mengenai teknis dan pedoman terhadap penyebaran Covid-19 diatur lebih lanjut dalam PMK Vaksin, pengaturan tersebut termasuk sasaran dari vaksin, jenis vaksin, jumlah vaksin, dll.

Pengaturan terhadap vaksin tersebut mengindikasikan bahwa Vaksin Covid-19 yang akan didistribusikan berasal dari WHO. Sehingga, dapat dikatakan Indonesia menunggu kedatangan vaksin dari organisasi dunia tersebut untuk didistribusikan. Akan tetapi, Indonesia dapat membuat vaksin tersendiri untuk diedarkan asalkan mendapat persetujuan dari WHO. Vaksin ditujukan kepada setiap Warga Negara Indonesia baik yang berada diluar negeri maupun dalam negeri, dikarenakan setiap Warga Negara Indonesia memiliki hak yang sama terutama dalam perlindungan penyakit yang mematikan.

Pengedaran vaksin kepada masyarakat dilakukan secara bertahap, bahkan terdapat golongan prioritas untuk penerima Vaksin Covid-19. Sebagaimana yang dijelaskan didalam pasal 8 ayat (4) PMK Vaksin bahwa yang termasuk didalam golongan prioritas yaitu tenaga kesehatan, Tentara Nasional Indonesia, Kepolisian Negara Republik Indonesia, aparat hukum, tokoh masyarakat, pelaku perekonomian, perangkat daerah, tenaga pendidik, aparatur kementerian/lembaga, dan masih banyak yang lainnya. Jika dilihat pada penjelasan tersebut bahwasannya golongan prioritas wajib diberikan vaksin paling pertama termasuk golongan prioritas yang berada di luar negeri. Untuk membantu menyebarkan vaksin Warga Negara Indonesia yang berada di luar negeri, sebagaimana dijelaskan didalam Pasal 26 ayat (1) PMK Vaksin bahwa Kementerian kesehatan dapat bekerjasama salah satunya kepada Kementerian/Lembaga lainnya. Sehingga Kementerian Kesehatan dapat melakukan kerjasama kepada Kementerian Luar Negeri untuk menindaklanjuti pemberian vaksin covid-19 di luar negeri dengan berkomunikasi dengan beberapa kantor konsulat Indonesia yang ada di beberapa negara.

Lockdown merupakan pembatasan sosial yang dilakukan di suatu wilayah untuk mencegah penyebaran suatu penyakit. Lockdown sebenarnya merupakan perluasan dari social distancing, yang mencakup wilayah dan territorial sehingga apabila suatu wilayah melakukan lockdown, maka artinya menutup pintu masuk dan pintu keluar bagi setiap masyarakat. Setiap negara menerapkan kebijakan mengenai Lockdown, bahkan ada beberapa kebijakan untuk melakukan Lockdown yang sangat ketat untuk mengurangi pencegahan penyebaran Covid-19.

Penjelasan didalam IHR terdapat pemisahan suatu objek yang dapat mengakibatkan klaster baru, sehingga karantina yang dilakukan oleh beberapa negara yaitu melarang setiap warga negaranya untuk bepergian atau travelling. Bahkan pengaturan terhadap isolasi atau karantina terhadap objek termasuk barang dan orang diatur didalam Pasal 18 IHR sehingga hal inilah yang menjadi dasar setiap negara untuk membentuk kebijakan mengenai Karantina.

Beberapa negara telah meratifikasi IHR termasuk Indonesia. Indonesia Jurnal IImu Sosial dan Humaniora | 200 
menurunkan kembali ke dalam Hukum Nasional yaitu kedalam UU No.6 Tahun 2018 tentang Kekarantinaan Kesehatan (UU Karantina). Penjelasan terhadap PSBB bahkan tertuang didalam UU Karantina dan tentu berdasarkan dengan IHR. PSBB pada UU Karantina termasuk kedalam kekarantinaan kesehatan, artinya pelaksanaan PSBB merupakan salah satu unsur dari Kekarantinaan kesehatan. Hal inilah yang menjadi dasar dibentuknya kebijakan mengenai PSBB didalam penanggulangan Covid-19.

Pengaturan mengenai PSBB didalam penanggulangan Covid-19 dituangkan didalam beberapa kebijakan baik dari pemerintah pusat hingga ke pemerintah daerah memiliki kebijakan terhadap PSBB. Hanya saja, setiap pemerintah daerah yang menetapkan kebijakan mengenai PSBB harus berdasar kebijakan dari pemerintah pusat sehingga selaras kebijakan dari pemerintah pusat dan pemerintah daerah. Adapun kebijakan terhadap PSBB di dalam penanggulangan Covid-19 tertuang didalam Peraturan Pemerintah Republik Indonesia No.21 Tahun 2020 tentang PSBB (PP PSBB) dan Peraturan Menteri Kesehatan RI No.9 Tahun 2020 tentang Pedoman Pembatasan Sosial Berskala Besar dalam Rangka Percepatan Penanganan Covid-19 (PMK Pedoman PSBB). Kebijakan tersebut tentu berdasarkan UU Karantina Kesehatan dan juga IHR.

$$
\text { Hak Asasi Manusia (HAM) }
$$

merupakan hak dimiliki oleh manusia berdasarkan martabatnya sebagai manusia. Gagasan mengenai HAM terletak di Pancasila, bahkan jauh sebelum dibentuknya Universal Declaration of Human Right (UDHR) pada Tahun 1948 Pancasila telah mengagas mengenai perlindungan mengenai HAM. Pengagasan mengenai HAM didalam Pancasila lebih dikarenakan nasib yang sama sebagai masyarakat yang dijajah, sehingga founding father pada saat itu yaitu Ir. Soekarno mengemukakan HAM tersebut kepada
Pancasila. Dalam Pancasila, terdapat hak manusia sejak ia lahir yang dibagi menjadi dua aspek yaitu aspek individualitas (pribadi) dan aspek sosialitas (masyarakat). Sehingga dari penjelasan mengenai aspek tersebut merupakan peran pemerintah untuk melindungi hak tersebut dan peran dari masyarakat untuk saling menghormati hak asasi manusia yang dimiliki masing-masing.

Hak asasi manusia merupakan hak yang tidak dapat dikurangi sedikitpun sehingga setiap manusia dapat menikmati haknya, akan tetapi terdapat aturan-aturan mengenai HAM untuk membatasi hakhaknya sehingga setiap manusia tidak menggunakan haknya melewati batas dan tetap menghargai hak orang lain. Dalam hal Pandemi Covid-19, hak-hak manusia yang telah dijelaskan di beberapa instrument hukum Internasional dan juga di beberapa peraturan perundang-undangan sebagian besar dibatasi oleh pemerintah mengingat pelaksanaan hak asasi manusia yang dilakukan oleh sebagian masyarakat akan menimbulkan klaster kasus baru terhadap pandemic covid-19. Salah satu pembatasan terhadap hak asasi manusia didalam Pandemi Covid-19 itu ialah pembatasan terkait pengumpulan massa atau berkumpul. Mengenai kondisi fundamental, Indonesia telah menyatakan bahwa Indonesia berada dalam keadaan darurat pada bulan Maret 2020 dengan Kepala Badan Nasional Penanggulangan Bencana yang menetapka hal tersebut. Dengan ditetapkannya keadaan darurat tersebut Indonesia dapat mengurangi hak-hak asasi manusia sesuai dengan amanat dari ICCPR, dan kebijakan yang dilakukan Indonesia untuk mengurangi hak asasi manusia tersebut ialah dengan memberlakukan Social Distancing atau pembatasan kerumunan massa yang dapat mengakibatkan klaster terhadap Pandemi Virus Covid-19.

Hak atas kesehatan merupakan hak yang fundamental dan pokok sehingga dapat mempengaruhi hak-hak yang lainnya

Jurnal IImu Sosial dan Humaniora | 201 
(Boleslawski et al., 2012; Zajacova et al., 2020). Terlebih dalam Pandemi Covid-19, hak atas kesehatan merupakan hak yang wajib diperhatikan karena berkaitan dengan penyakit (Wang et al., 2020). Kebijakankebijakan terhadap hak atas kesehatan telah diatur didalam beberapa hukum nasional untuk menjamin standar kesehatan yang tinggi.

Adapun aspek terhadap hak atas kesehatan diantaranya: (1) Hak Atas Kesehatan adalah hak inklusif. Maksudnya ialah hak atas kesehatan merupakan hak yang harus dipenuhi karena salah satu hak yang menunjang hak pokok manusia yakni hak untuk hidup. Komite Hak Ekonomi, Sosial dan Budaya yakni badan yang bertanggung jawab terhadap pemantauan kovenan Internasional tentang Hak Ekonomi, Sosial dan Budaya atau lebih tepatnya hal yang dapat mencapai tujuan sehat; (2) Hak atas kesehatan mengandung kebebasan. Maksud dari kebebasan disini ialah hak untuk bebas dari perawatan medis non-konsensual seperti percobaan dan penelitian medis atau sterilisasi paksa dan untuk mendapatkan kebebasan dari penyiksaan, kekejaman, tidak manusiawi atau merendahkan martabat lainnya didalam pengobatan; (3) Hak atas kesehatan; (4) Penyediaan Layanan, barang dan fasilitas kesehatan tanpa memandang ras ataupun tanpa adanya diskriminasi, Non-diskriminasi merupakan hal yang paling penting demi mewujudkan standar kesehatan yang tinggi yang ingin dicapai; (5) Semua layanan, barang dan fasilitas harus tersedia, dapat diakses, dapat diterima dan berkualitas baik.

Aspek hak atas kesehatan tersebut merupakan aspek yang wajib dipenuhi oleh Indonesia dan pemenuhan terhadap hak atas kesehatan dijamin berdasarkan peraturan perundang-undangan. UndangUndang yang menjamin mengenai kesehatan dituangkan UU Nomor 36 Tahun 2009 tentang Kesehatan. Penjelasan mengenai penjaminan terhadap hak atas kesehatan dijelaskan di Pasal 4 yang menyatakan "Setiap orang berhak atas kesehatan", sehingga hal ini yang menjadi dasar pemerintah didalam memenuhi hak atas kesehatan setiap warganya. Maka dari itu, kebijakan-kebijakan baru yang ditetapkan oleh pemerintah didalam memenuhi Hak Atas kesehatan tersebut diantaranya Keputusan Menteri Kesehatan RI No.HK.01.07/MENKES/275/2020 tentang Penetapan Rumah Sakit Rujukan Penanggulangan Penyakit Infeksi Emerging tertentu, Peraturan Presiden No.99 Tahun 2020 tentang Pengadaan Vaksin dan Pelaksanaan Vaksinasi, dan terdapat beberapa kebijakan lainnya.

Penyebaran covid-19 di Indonesia sangat mempengaruhi kesehatan, kesehatan yang dimaksud tidak hanya berupa fisik, namun berpengaruh terhadap mental health. Karena dibandingkan dengan aspek yang lain, kesehatan merupakan salah satu kebutuhan pokok manusia dan tanpa hidup sehat hidup manusia menjadi tanpa arti (Anugrahana, 2020; Kurniati et al., 2020; Yunitasari \& Hanifah, 2020). Meskipun telah terdapat aturan yang mengatur tentang kesehatan dibawah Undang-Undang Nomor 36 Tahun 2009 tentang Kesehatan, akan tetapi pengaturan untuk menanggulangi penyebaran covid-19 di Indonesia tidak hanya cukup berdasarkan UU Kesehatan saja, dibutuhkan kebijakankebijakan dari pemerintah untuk menanggulangi Covid-19 dengan berdasar kepada ideologi negara dan juga Konvensi Internasional.

Konvensi Internasional dibentuk dibawah naungan organisasi Internasional, sehingga negara-negara yang meratifikasi konvensi tersebut terikat dan tunduk terhadap Konvensi Internasional tersebut sesuai dengan asas Pacta Sunt Servanda (Rahayu \& Febriaty, 2017; Sabet et al., 2018; Suryaman, 2015). Termasuk Indonesia yang telah meratifikasi beberapa Konvensi Internasional kedalam Hukum Nasional beberapa contohnya: Undang-

Jurnal IImu Sosial dan Humaniora| 202 
Undang No. 11 Tahun 2005 tentang Pengesahan International Covenant on Economic, Social and Cultural Rights, Undang-Undang No. 12 Tahun 2005 tentang Pengesahan International Covenant on Civil and Political Rights (ICCPR), dll. Sehingga, kebijakan yang diterapkan oleh pemerintah didalam penanggulangan Covid-19 berdasar kepada Konvensi Internasional (Galih, 2017; Olivia et al., 2020; Yunus et al., 2020).

Penelitian ini didukung oleh beberapa penelitian sebelumnya yang relevan dengan penelitian ini yaitu: (1) penelitian yang dilakukan oleh (Kurniati et al., 2020), yang mendapatkan hasil penelitian bahwa peran orang tua sangat penting dalam mendampingi anak di masa pandemic covid19; (2) penelitian yang dilakukan oleh (Fitriyani et al., 2020), yang mendapatkan hasil penelitian bahwa pelaksanaan kegiatan pendidikan dilaksanakan secara daring selama pandemic covid-19; (3) penelitian yang dilakukan oleh (Pratama et al., 2020), yang mendapatkan hasil penelitian bahwa penggunaan media pendidikan efektif digunakan dimasa pandemic covid-19. Penelitian lain juga dilakukan oleh (Chen et al., 2021) menyatakan bahwa orang cenderung lebih memperhatikan hasil pertempuran pemerintah mereka melawan COVID-19 (jumlah kasus yang dikonfirmasi dan kematian per juta populasi) daripada kebijakan apa yang dimulai oleh pemerintah mereka.

\section{SIMPULAN DAN SARAN}

Kebijakan Pemerintah didalam menanggulangi Pandemi Covid-19 dibagi menjadi dua kategori yaitu kebijakan didalam bidang kesehatan dan dalam hal hak asasi manusia. Dalam bidang kesehatan terdapat kebijakan-kebijakan yang tujuannya untuk menanggulangi beberapa diantaranya yaitu pemberian vaksin dan juga penetapan Lockdown. Selanjutnya, dalam hal hak asasi manusia, dalam menanggulangi Covid-19 terdapat beberapa hal penting yang wajib diperhatikan Indonesia untuk melancarkan penanggulangan Covid-19. Pembatasan hak asasi manusia wajib diperhatikan mengingat beberapa hak asasi manusia yang dipenuhi oleh negara kemungkinan menimbulkan klaster terbaru, salah satunya ialah hak untuk berkumpul sehingga berdasarkan konvensi Internasional ICCPR, Indonesia memiliki kewenangan untuk melakukan pembatasan terhadap hak-hak asasi manusia. Dalam Pandemi Covid-19 pula, hak atas kesehatan merupakan hak yang wajib untuk diperhatikan, dikarenakan hak atas kesehatan bersinggungan dengan Covid-19 ini sehingga pemenuhan aspekaspek kesehatan yang dilakukan oleh negara kepada warganya sangat mempengaruhi penyebaran dari Covid-19.

\section{DAFTAR PUSTAKA}

Andiarna, F., \& Kusumawati, E. (2020). Pengaruh Pembelajaran Daring terhadap Stres Akademik Mahasiswa Selama Pandemi Covid-19. Jurnal Psikologi Fakultas Psikologi UIN Sultan Syarif Kasim Riau, 16(2). https://doi.org/10.24014/jp.v16i2.1039 5

Anugrahana, A. (2020). Hambatan, Solusi dan Harapan: Pembelajaran Daring Selama Masa Pandemi Covid-19 Oleh Guru Sekolah Dasar. Scholaria: Jurnal Pendidikan Dan Kebudayaan, 10(3), 282-289.

Boleslawski, E., Decanter, G., Truant, S., Bouras, A. F., Sulaberidze, L., Oberlin, O., \& Pruvot, F. R. (2012). Right hepatectomy with extra-hepatic vascular division prior to transection: Intention-to-treat analysis of a standardized policy. Hpb, 14(10), 688699. https://doi.org/10.1111/j.14772574.2012.00519.x

Chen, C. W. S., Lee, S., Dong, M. C., \& Taniguchi, M. (2021). What factors

Jurnal IImu Sosial dan Humaniora| 203 
drive the satisfaction of citizens with governments' responses to COVID19? International Journal of Infectious Diseases, 102, 327-331. https://doi.org/10.1016/j.ijid.2020.10.0 50

Dewi, E. U. (2020). Pengaruh Kecemasan Saat Pembelajaran Daring Masa Pandemi Covid-19 Terhadap Prestasi Belajar Mahasiswa Stikes William Surabaya. Jurnal Keperawatan, 9(1). https://doi.org/10.47560/kep.v9i1.210

Fitriyani, Y., Fauzi, I., \& Sari, M. Z. (2020). Motivasi Belajar Mahasiswa Pada Pembelajaran Daring Selama Pandemik Covid-19. Jurnal Kependidikan: Jurnal Hasil Penelitian Dan Kajian Kepustakaan Di Bidang Pendidikan, Pengajaran Dan Pembelajaran, 6(2), 165-175. https://doi.org/10.23917/ppd.v7i1.109 73

Galih, Y. S. (2017). Kewajiban Negara Melindungi Anak Bangsa. Jurnal IImiah Galuh Justisi, 5(1). https://doi.org/10.25157/jigj.v5i1.249

Goldschmidt, K. (2020). The COVID-19 Pandemic: Technology use to Support the Wellbeing of Children. Journal of Pediatric Nursing, 53, 88-90. https://doi.org/10.1016/j.pedn.2020.04 .013

Herliandry, L. D., Nurhasanah, Suban, M. E., \& Kuswanto, H. (2020). Pembelajaran Pada Masa Pandemi Covid-19. Jurnal Teknologi Pendidikan, 22(1), 65-70. https://doi.org/10.21009/jtp.v22i1.1528 6

Kurniati, E., Nur Alfaeni, D. K., \& Andriani, F. (2020). Analisis Peran Orang Tua dalam Mendampingi Anak di Masa Pandemi Covid-19. Jurnal Obsesi: Jurnal Pendidikan Anak Usia Dini, 5(1), 241.

https://doi.org/10.31004/obsesi.v5i1.5 41

Olivia, S., Gibson, O., \& Nasrudin, R. (2020). Indonesia in the Time of Covid-19.
Bulletin of Indonesian Economic Studies, 56(2), 143-174. https://doi.org/10.1080/00074918.202 0.17

Pratama, L. D., Lestari, W., \& Astutik, I. (2020). Efektifitas Penggunaan Media Edutainment Di Tengah Pandemi Covid-19. AKSIOMA: Jurnal Program Studi Pendidikan Matematika, 9(2), 413-423.

https://doi.org/10.24127/ajpm.v9i2.278 3

Rahayu, S. E., \& Febriaty, H. (2017). Penerapan Model Pembelajaran Contextual Teaching And Learning (CTL) Untuk Meningkatkan Pemahaman Materi Pasar Valuta Asing Pada Mata Kuliah Ekonomi Internasional 2 (Studi Mahasiswa Semester 5 Jurusan Ekonomi Pembangunan Fakultas Ekonomi UMSU). Jurnal IImiah Manajemen Dan Bisnis, 17(2), 94-107. https://doi.org/10.30596/jimb.v17i2.96 0

Sabet, M., Zafarghandi, A., Prasojo, L., Idi, A., \& Karkaraq, A. (2018). Pengaruh Tugas Pemecahan Masalah pada Membaca Kritis Siswa EFL Menengah dalam Konteks Iran. Jurnal Internasional Linguistik Terapan \& Sastra Inggris. https://doi.org/10.7575/aiac.ijalel.v.7n. $1 \mathrm{p} .99$

Suryaman, M. (2015). Analisis Hasil Belajar Peserta Didik Dalam Literasi Membaca Melalui Studi Internasional (Pirls) 2011. Litera, 14(1), 170-186. https://doi.org/10.21831//tr.v14i1.4416

Wang, Z., Duan, Y., Jin, Y., \& Zheng, Z.-J. (2020). Coronavirus disease 2019 (COVID-19) pandemic: how countries should build more resilient health systems for preparedness and response. Global Health Journal, 4(4), 139-145.

https://doi.org/10.1016/j.glohj.2020.12. 001

Jurnal IImu Sosial dan Humaniora | 204 
Yunitasari, R., \& Hanifah, U. (2020). Pengaruh Pembelajaran Daring terhadap Minat Belajar Siswa pada Masa COVID 19. Edukatif: Jurnal IImu Pendidikan, 2(3), 236-240. https://doi.org/10.31004/edukatif.v2i3. 142

Yunus, Rohim, N., \& Rezki, A. (2020). Kebijakan Pemberlakuan Lockdown Sebagai Antisipasi Penyebaran Corona Virus Covid-19. Jurnal Sosial \& Budaya Syar-I FSH UIN Syarif Hidayatullah Jakarta, 7(3), 227-238. https://doi.org/10.15408/sjsbs.v7i3.15 083

Zajacova, A., Jehn, A., Stackhouse, M., Choi, K. H., Denice, P., Haan, M., \& Ramos, H. (2020). Mental health and economic concerns from March to May during the COVID-19 pandemic in Canada: Insights from an analysis of repeated cross-sectional surveys. SSM - Population Health, 12, 100704. https://doi.org/10.1016/j.ssmph.2020.1 00704 